\title{
OBOWIĄZEK ZAWIADAMIANIA STRON O KONTYNUACJI ROZPRAWY W ASPEKCIE GWARANCJI PROCESOWYCH ORAZ ZASADY KONCENTRACJI PROCESU
}

Podstawowym uprawnieniem stron procesowych w stadium postępowania jurysdykcyjnego jest możliwość brania udziału w rozprawie głównej, czyli na forum, na którym rozpoznawana jest kwestia odpowiedzialności prawnej oskarżonego za zarzucany mu czyn. Zapewnienie przez ustawę rzeczywistej możliwości udziału stron w rozprawie głównej świadczy o respektowaniu przez dany system prawny najważniejszych zasad procesowych, przede wszystkim: trafnej reakcji karnej, kontradyktoryjności, równouprawnienia stron, obrony, skargowości, prawdy materialnej, bezpośredniości czy rzetelnego procesu ${ }^{1}$.

W tym kontekście należy zwrócić uwagę, że przepisy przewidujące obecność stron na rozprawie, nakazujące zawiadamianie ich o kolejnym terminie rozprawy, unormowania dotyczące zawiadomień (w tym doręczeń) oraz wyżej wskazane zasady procesu stanowią - w odpowiednim zakresie - gwarancje procesowe (stron, a także trafnej reakcji karnej, dobra wymiaru sprawiedliwości i interesu społecznego $)^{2}$. Podkreśla to rolę regulacji procesowych dotyczących zawiadamiania stron (w tym doręczeń) i przekonuje, że nie sposób ich uznać za mające jedynie charakter techniczno-porządkowy ${ }^{3}$.

Uczestnictwo większości stron w rozprawie jest $\mathrm{z}$ reguły ich uprawnieniem, a nie obowiązkiem ${ }^{4}$. W tym stanie rzeczy zaakcentować trzeba, że umożliwienie

\footnotetext{
${ }^{1}$ Przyjmuje się tu określenia zasady procesowej i gwarancji procesowej podane przez M. Cieślaka. W odniesieniu do definicji zasady procesowej por. M. Cieślak, Polska procedura karna. Podstawowe zatożenia teoretyczne, Warszawa 1984, s. 196-197. W ujęciu tego autora zasady prawne, obok konkretnych przepisów ustaw i innych norm prawnych, które wynikają wprost lub pośrednio z przepisów ustawy oraz całych instytucji danego systemu prawnego, stanowią ustawowe środki zabezpieczające określone prawa lub interesy w procesie karnym (gwarancje karnoprocesowe); bliżej ibidem, s. 479.

${ }^{2}$ Por. ibidem, s. 480-484; K. Marszał, Proces karny. Zagadnienia ogólne, Katowice 2008, s. 28-30.

${ }^{3}$ Podkreślają to słusznie w szczególności: S. Sliwiński, Polski proces karny przed sadem powszechnym. Zasady ogólne, Warszawa 1948, s. 539; W. Daszkiewicz, Prawo karne procesowe. Zagadnienia ogólne, t. 2, Bydgoszcz 2001, s. 55-56.

${ }^{4}$ Obowiązek brania udziału w rozprawie dotyczy tylko niektórych stron (oskarżony, oskarżyciel publiczny), i to nie we wszystkich trybach postępowania (postępowanie zwyczajne). Por. np. art. 46, 374 $\S 1$ k.p.k. W odniesieniu do oskarżonego podnosi się niekiedy, że przybiera on postać raczej względnej fakultatywności; por.: J. Kudrelek, Obecność oskarżonego na rozprawie głównej - prawo czy obowiazek? Uwagi de lege lata $i$ de lege ferenda, w: Z. Sobolewski, G. Artymiak, C. P. Kłak, Problemy znowelizowanej procedury karnej, Kraków 2004, s. 54, 75-76; S. Stachowiak, Rozprawa główna prowadzona pod nieobecność oskarżonego $w$ polskim procesie karnym, „Prokuratura i Prawo” 1999, nr 4, s. 8-9; M. J. Urbaniak, Rozpoznawanie spraw pod nieobecność oskarżonego $w$ polskim procesie karnym,
} 
stronom wzięcia udziału $\mathrm{w}$ rozprawie realizuje przysługujące im gwarancje, urzeczywistnia szereg zasad procesowych (zwłaszcza równouprawnienia stron, obrony, rzetelnego procesu) i jedynie stwarza, w uzależnieniu od tego, czy strony zechcą skorzystać z przysługujących im uprawnień, potencjalne warunki do realizacji innych zasad (w szczególności trafnej reakcji karnej, kontradyktoryjności, prawdy materialnej, bezpośredniości).

Obowiązek zawiadamiania stron o kontynuacji rozprawy warto rozpatrywać z perspektywy dwubiegunowego układu ustawowych środków zabezpieczających interesy indywidualne i interes społeczny. Pojęcia gwarancji procesowych stron oraz zasady koncentracji procesu odzwierciedlają bowiem kierunki kluczowych interesów, jakie ścieraja się w toku postępowania, a mianowicie: interesów indywidualnych (przede wszystkim stron) oraz interesu społecznego. Gwarancje procesowe stron oraz zasadę koncentracji procesu wypada zestawić na jednej płaszczyźnie rozważań, gdyż zasada koncentracji procesu jest w odniesieniu do omawianej kwestii najważniejszym ustawowym środkiem zabezpieczającym interes społeczny ${ }^{5}$. Z punktu widzenia stron na pierwszym planie sytuują się bowiem ich gwarancje procesowe, zwłaszcza dotyczące możności uczestnictwa w rozprawie, prezentowania swego stanowiska i dążenia do uzyskania jak najlepszej sytuacji procesowej, które nie moga doznać uszczuplenia. Natomiast $\mathrm{z}$ punktu widzenia interesu społecznego rzecz sprowadza się w tym zakresie do dbałości o koncentrację procesu ${ }^{6}$, tak by wyeliminować zbędne przerywanie lub odraczanie rozprawy.

Problem rozważenia kwestii zawiadamiania stron o kontynuacji rozprawy aktualizuje się w sytuacji, gdy następuje przerwanie ciąłości rozprawy. Na gruncie obowiązującego prawa ma to miejsce $\mathrm{W}$ związku $\mathrm{z}$ następującymi instytucjami procesowymi:

1) zawieszeniem postępowania (art. $22 \S 1$ k.p.k.),

2) odroczeniem rozprawy (art. $404 \S 1$ k.p.k.),

3) przerwą w rozprawie (art. $401 \S 1$ k.p.k.),

4) odroczeniem wydania wyroku (art. $411 \S 1$ k.p.k.),

5) wznowieniem przewodu sądowego (art. 409 k.p.k.).

Poznań-Kalisz 2003, s. 197-198; P. Rogoziński, Obecność oskarżonego na rozprawie sadowej i jego prawo do prowadzenia obrony materialnej $w$ świetle norm konstytucyjnych i konwencyjnych, „Gdańskie Studia Prawnicze" 4, 1999, s. 97-98.

${ }^{5}$ Szeroko na ten temat pisze J. Kudrelek, Zasada ciagtości w postępowaniu karnym, Szczytno 2008, s. 101-107.

${ }^{6}$ Mówiąc o zasadzie koncentracji procesu, rozumie się przez to dyrektywę, w myśl której proces powinien stanowić zwarty, konsekwentny ciąg czynności i zdarzeń, bez przerw i zahamowań. Zasada koncentracji procesu pozostaje w ścisłym związku z zasadą szybkości, lecz nie jest jej zwykłą konsekwencją. Choć koncentracja jest uzależniona od szybkości, to wykracza ona poza tę cechę i skupia się raczej na zagadnieniu sprawności postępowania. To sprawność jest zasadniczym punktem odniesienia interesu społecznego, gdyż stanowi aksjologicznie pozytywną cechę przebiegu procesu, podczas gdy szybkość może mieć również negatywne konotacje. Por. bliżej: M. Cieślak, op. cit., s. 341-343; J. Grajewski, w: J. Grajewski (red.), Prawo karne procesowe - część ogólna, Warszawa 2011, s. 106; J. Tylman, w: T. Grzegorczyk, J. Tylman, Polskie postępowanie karne, Warszawa 2011, s. 173; R. Kmiecik, w: R. Kmiecik, E. Skrętowicz, Proces karny. Czéść ogólna, Warszawa 2009, s. 107-108; K. Marszał, op. cit., s. 94-95 oraz obszernie A. Murzynowski, Zasada ciagtości rozprawy w polskim procesie karnym, w: P. Hofmański, K. Zgryzek, Wspótczesne problemy procesu karnego i wymiaru sprawiedliwości. Ksiega ku czci Profesora Kazimierza Marszata, Katowice 2003, s. 273-276, 281. 
Zasadę ogólną formułuje art. 117 § 1 k.p.k., wedle którego uprawnionego do wzięcia udziału w czynności procesowej ( $\mathrm{w}$ tym w rozprawie) zawiadamia się o jej czasie i miejscu, chyba że ustawa stanowi inaczej. Konsekwencją niezawiadomienia strony albo braku dowodu zawiadomienia - jeżeli strona nie stawiła się - jest niemożność przeprowadzenia czynności procesowej, nawet gdy ustawa nie przewiduje obowiązku stawiennictwa danej strony na rozprawę (por. art. 117 § 2 k.p.k.) ${ }^{7}$. Uprzedzając nieco późniejsze uwagi, należy dodać, że $\mathrm{w}$ odniesieniu do rozpatrywanego zagadnienia problem pojawia się $\mathrm{w}$ sytuacji, gdy przerwanie ciągłości rozprawy następuje $\mathrm{z}$ jednoczesnym wskazaniem czasu i miejsca jej kontynuowania. Wówczas dopiero powstaje kwestia obowiązku i celowości zawiadamiania stron (obecnych oraz nieobecnych w chwili przerwania ciągłości) o czasie i miejscu kontynuowania rozprawy ${ }^{8}$.

Z tego właśnie powodu nie budzi większych kontrowersji w interesującym tu zakresie zagadnienie zawiadamiania stron $\mathrm{w}$ związku $\mathrm{z}$ zastosowaniem instytucji zawieszenia postępowania. Skoro za „długotrwałą przeszkodę” uniemożliwiająca prowadzenie postępowania, w rozumieniu art. $22 \S 1$ k.p.k., uznaje się taką, której termin ustania bądź w ogóle jest trudny do ustalenia, bądź co najmniej jest tak odległy w czasie, że przekracza wszelkie racjonalnie dopuszczalne okresy odroczenia rozprawy, nie mówiąc już o okresie przerwy ${ }^{9}$, to praktycznie zawsze, gdy sąd postanawia o zawieszeniu postępowania jurysdykcyjnego, nie określa on jednocześnie czasu ani miejsca kontynuowania rozprawy. Po wydaniu postanowienia o podjęciu postępowania należy zawiadomić (wezwać) wszystkie strony o terminie wyznaczonej rozprawy głównej, stosownie do art. $117 \S 1$ k.p.k.

Zgoła odmienna sytuacja może mieć miejsce w odniesieniu do instytucji przerwy w rozprawie. Ustawa nie nakłada na przewodniczącego zarządzającego przerwę obowiązku jednoczesnego wskazania czasu i miejsca kontynuowania rozprawy, choć w praktyce jest to reguła ${ }^{10}$. Jeżeli przewodniczący, zarządzając przerwę, nie dokona tego wskazania, to jest oczywiste, że po wyznaczeniu czasu i miejsca kontynuowania rozprawy wydanym później osobnym zarządzeniem konieczne jest zawiadomienie (wezwanie) o tym wszystkich stron na zasadach ogólnych (art. 117 § 1 k.p.k.).

Z kolei, zgodnie $\mathrm{z}$ art. $402 \S 1$ k.p.k., jeżeli przewodniczący, zarządzając przerwę, oznaczy jednocześnie czas i miejsce dalszego ciagu rozprawy, osoby obecne na rozprawie przerwanej są obowiązane stawić się w nowym terminie

${ }^{7}$ Ustawa przewiduje $\mathrm{w}$ tym zakresie wyjątki, np. oświadczenie obrońcy, że oskarżony wiedział o terminie, jak też w art. 249 § 3, art. 316 § 1 k.p.k. Por. również P. Hofmański, E. Sadzik, K. Zgryzek, Kodeks postepowania karnego. Komentarz, t. 1, Warszawa 2011, s. 740-741.

${ }^{8}$ Por. również uwagi zamieszczone w uzasadnieniu postanowienia Sądu Najwyższego z 3 lutego 2004 r., III KK 274/03, OSNwSK 2004, poz. 248.

${ }^{9}$ Wyrok Sądu Najwyższego z 8 grudnia 1978 r., Rw 447/78, OSNKW 1979, z. 5, poz. 59 z aprobującymi uwagami W. Mendyki (,Wojskowy Przegląd Prawniczy” 1979, nr 3, s. 345), H. Kmieciaka, T. Kacperskiego (,,Wojskowy Przegląd Prawniczy” 1979, nr 4, s. 462), M. Cieślaka, Z. Dody („Palestra” 1980, nr 2, s. 39) oraz W. Daszkiewicza („Państwo i Prawo” 1980, z. 4, s. 119); Z. Gostyński, Zawieszenie postepowania $w$ nowym ustawodawstwie karnoprocesowym, Warszawa 1998, s. 29-31.

${ }^{10}$ Celowość jednoczesnego wskazania czasu i miejsca kontynuowania rozprawy po przerwie jest bowiem uzależniona od powodu przerwania rozprawy, por. P. Hofmański, E. Sadzik, K. Zgryzek, op. cit., t. 2, s. 603-604. 
bez wezwania. W doktrynie słusznie zwrócono uwagę, że przepis ten jest mało precyzyjny, a jego sens sprowadza się do tego, iż nie jest konieczne wysyłanie wezwań na kolejny termin rozprawy ani też zawiadomień do osób, które były obecne na rozprawie przerwanej i w związku z tym przyjęły nowy termin do wiadomości ${ }^{11}$. Należy też uznać, że w świetle art. $402 \S 1$ k.p.k. obowiązek stawiennictwa $\mathrm{w}$ kolejnym wyznaczonym terminie nie obejmuje wszystkich uczestników obecnych na rozprawie przerwanej, lecz dotyczy tylko tych, na których spoczywa on $\mathrm{z}$ racji roli, jaką pełnia $\mathrm{w}$ postępowaniu ${ }^{12}$. Natomiast uczestnicy, którzy na rozprawie przerwanej korzystali ze swojego prawa do obecności na niej (np. oskarżyciel posiłkowy), mają takie samo prawo (a nie obowiązek) do stawiennictwa także w nowo oznaczonym terminie, przy czym wolno uznać je za zawiadomione o nim $^{13}$.

W literaturze wyrażono też pogląd, że brzmienie art. $402 \S 1$ k.p.k. pozwala na wyciągnięcie a contrario wniosku, iż $\mathrm{w}$ razie zarządzenia przerwy oraz oznaczenia terminu i miejsca kontynuacji rozprawy, zachodzi konieczność wezwania na nowy termin uczestników, którzy mają obowiązek stawiennictwa, a nie byli obecni na rozprawie przerwanej, oraz zawiadomienia tych, którzy nie byli obecni na rozprawie przerwanej, a maja prawo stawić się na rozprawę w nowym terminie ${ }^{14}$. Należy jednak zauważyć, że -inaczej niż w odniesieniu do odroczenia rozprawy - ustawodawca nie wypowiedział się na temat minimalnego czasu trwania przerwy. W konsekwencji przerwa w rozprawie może trwać np. pięć minut, pół godziny, pięć godzin, dwa dni, dwa tygodnie, czy 35 $\mathrm{dni}^{15}$. Długość okresu przerwy powinna odzwierciedlać przyczynę, z powodu której przerwę zarządzono ${ }^{16}$. Niekiedy w praktyce wyróżnia się tzw. przerwy techniczne, przeznaczone na rozwiązanie doraźnej kwestii o takim właśnie charakterze, $\mathrm{np}$. usunięcie zakłóceń $\mathrm{w}$ transmisji połączenia $\mathrm{z}$ osobą przesłuchiwana w trybie art. $177 \S 1 \mathrm{a}$ k.p.k. czy oczekiwanie na stawiennictwo świadków wezwanych na określona, późniejszą godzinę. Kodeks jednak nie czyni żadnej dyferencjacji pomiędzy przerwami zarządzanymi z różnych powodów i na różny okres, tak więc nie ma prawnych podstaw do wskazywania jakichś szczególnych kategorii przerw. Powstaje w związku z tym pytanie, czy zachodzi konieczność wezwania na nowy termin uczestników, którzy maja obowiązek stawiennictwa, a nie byli obecni na rozprawie przerwanej, oraz zawiadomienia tych, którzy nie byli obecni na rozprawie przerwanej, a maja

11 Ibidem, s. 604.

${ }^{12}$ Por. ibidem, s. 604; R. A. Stefański, w: Z. Gostyński (red.), Kodeks postẹpowania karnego. Komentarz, t. 2, Warszawa 2004, s. 772; A. Ważny, w: K. T. Boratyńska et al., Kodeks postępowania karnego. Komentarz, Warszawa 2012, s. 854. Odmiennie, jak się wydaje: L. K. Paprzycki, w: J. Grajewski, L. K. Paprzycki, S. Steinborn, Kodeks postepowania karnego. Komentarz, t. 1, Warszawa 2010, s. 1226.

${ }^{13}$ Por. P. Hofmański, E. Sadzik, K. Zgryzek, op. cit., t. 2, s. 604.

${ }^{14}$ Ibidem, s. 604; R. A. Stefański, w: Kodeks postępowania..., s. 772.

${ }^{15}$ Por.: M. Cieślak, op. cit., s. 345; L. K. Paprzycki, w: J. Grajewski, L. K. Paprzycki, S. Steinborn, op. cit., s. 1226; A. Ważny, w: K. T. Boratyńska et al., op. cit., s. 853.

${ }^{16}$ A. Bojańczyk, T. Razowski, W kwestii optymalnego czasu przerwy $i$ odroczenia $w$ postępowaniu karnym, w: J. Warylewski (red.), Czas $i$ jego znaczenie $w$ prawie karnym, Gdańsk 2010, s. 65-66; J. Kudrelek, Zasada ciagtości..., s. 281-282; A. Murzynowski, op. cit., s. 276. Por. również ibidem, s. 270-271 na temat stanowiska Komisji Kodyfikacyjnej k.p.k. z 1928 r., a także wyrok Sądu Najwyższego z 10 stycznia 1977 r., V KR 215/76, OSNKW 1977, z. 6, poz. 64. 
prawo stawić się na rozprawę $\mathrm{w}$ nowym terminie, również $\mathrm{w}$ wypadku przerwania rozprawy. Jak w związku z tym dokonać zawiadomienia (wezwania) nieobecnych uczestników, aby po pierwsze uczynić to zgodnie $\mathrm{z}$ regułami wskazanymi w rozdziale 15 k.p.k., a po drugie, by rzeczywiście umożliwić im stawiennictwo na rozprawę po jej przerwaniu? Gdyby zaś przyjąć, że obowiązek zawiadomienia (wezwania) nie dotyczy przerwania rozprawy na tak krótki okres, to w jakich wypadkach taki obowiązek istnieje, a w jakich nie? Pytania te nabierają dodatkowej ostrości na gruncie uregulowań trybów uproszczonego i przyspieszonego, które przewiduja jeszcze krótsze maksymalne okresy trwania przerwy w rozprawie. Czy zatem pozostaje jedynie alternatywa: albo zawiadamianie (wzywanie) takich uczestników we wszystkich wypadkach zarządzenia przerwy, bez względu na jej długość, albo też nieczynienie tego w żadnej sytuacji?

Zwrócić też trzeba uwagę na to, że w systemie prawa procesowego występuja unormowania wprost przewidujące zawiadamianie oskarżonego o terminie rozprawy przerwanej - art. $376 \S 2$, art. 377 § 1 i 5 oraz art. $377 \S 3$ i 5 k.p.k. Pierwszy wypadek nie budzi kontrowersji, o ile oskarżony był obecny na poprzednim terminie rozprawy i o ile przy zarządzeniu przerwy oznaczono jednocześnie czas i miejsce dalszego ciągu rozprawy. W pozostałych sytuacjach sprawa jest bardziej złożona, gdyż oskarżony nie był obecny (lub był niezdolny do udziału w rozprawie) i tym samym nie przyją do wiadomości czasu ani miejsca kontynuowania rozprawy po przerwie. Wydaje się przy tym, że zasada równości stron nakazywałaby przyjęcie unormowań dotyczacych zawiadamiania oskarżonego również i do pozostałych stron ${ }^{17}$. Uogólniając, można stwierdzić, że regulacje te zezwalają na kontynuację przerwanej rozprawy pod nieusprawiedliwiona nieobecność oskarżonego, jeżeli uprzednio nie był on obecny na rozprawie, ale został zawiadomiony o czasie i miejscu jej kontynuowania po przerwie. W dalszym jednak ciagu aktualne pozostaje pytanie, czy unormowania te dotyczą wszystkich przerw, a zwłaszcza tak krótkich, że samo zawiadomienie nieobecnych stron o kontynuacji rozprawy, tym bardziej zaś umożliwienie im stawiennictwa, byłoby praktycznie nierealne ${ }^{18}$. Gdyby w myśl przedstawionej powyżej alternatywy: albo zawiadamianie stron we wszystkich wypadkach zarządzenia przerwy, bez względu na jej długość, albo też nieczynienie tego w żadnym wypadku - opowiedzieć się za jej pierwszym członem, wówczas taka faktyczna niemożność przerywania rozpraw na krótki okres musiałaby konsekwentnie występować również w szeregu innych wypadków, o których mowa w art. $376 \S 1$, art. $376 \S 3$, art. $479 \S 1$ i art. $517 \mathrm{e}$ $\S 2$ k.p.k., gdy decyzja o przerwaniu rozprawy i o wyznaczeniu terminu jej kontynuowania zapadła pod nieobecność chociaż jednej ze stron.

${ }^{17}$ Por. uwagi M. Wąsek-Wiaderek, Zasada równości stron w polskim procesie karnym w perspektywie prawnoporównawczej, Kraków 2003, s. 278-283.

${ }^{18} \mathrm{~W}$ literaturze zgodnie podkreśla się, że regulacja art. 117 k.p.k. ma stanowić gwarancję prawa osób uprawnionych do brania udziału w czynnościach procesowych, a zawiadamianie o tych czynnościach jedynie temu służy. Por.: Z. Gostyński, w: Z. Gostyński (red.), Kodeks postepowania karnego. Komentarz, t. 1, Warszawa 2003, s. 675; P. Hofmański, E. Sadzik, K. Zgryzek, op. cit., t. 1, s. 740; A. Sakowicz, w: K. T. Boratyńska et al., op. cit., s. 293. 
Przeciwko wykładni językowej przemawiaja racje natury funkcjonalnej i jurydycznej. Jak wyżej zaznaczono, należy mieć na względzie cel (ratio legis) instytucji przerwy w rozprawie ${ }^{19}$. Zauważyć trzeba, że z praktycznego punktu widzenia nieracjonalne i nierzadko niemożliwe jest dokonywanie zawiadomień stron $\mathrm{w}$ wypadkach przerwania rozprawy na krótki okres, nie mówiąc już o nierealności stawiennictwa tych osób ${ }^{20}$. Skoro nie przybyły one na przerwana rozprawę, to trudno oczekiwać, aby przyczyny tego niestawiennictwa ustały w sytuacji jej kontynuowania po bardzo krótkim czasie. Jeżeli chodzi o sposoby dokonywania doręczeń w takich sytuacjach, to - ze względu na ewentualność potrzeby awizowania przesyłek - w praktyce odpadałaby możliwość „tradycyjnych" doręczeń przez podmioty określone w art. $131 \S 1$ k.p.k. Pozostawałoby właściwie jedynie skorzystanie z telefaksu, poczty elektronicznej (art. 132 $\S 3$ k.p.k.) lub telefonu (art. 137 k.p.k.), choć bez żadnych gwarancji rzeczywistego dotarcia przekazanego $\mathrm{w}$ ten sposób komunikatu do wiadomości osoby zainteresowanej ${ }^{21}$.

Poza tym warto zauważyć, że akceptacja bez zastrzeżeń pierwszego stanowiska prowadziłaby do nieuzasadnionego odstępstwa od zasad szybkości i koncentracji procesu oraz faktycznego zacierania różnic pomiędzy przerwą a odroczeniem rozprawy. Krótkotrwałe przerwy są z punktu widzenia praktyki użyteczne do prawidłowego przeprowadzenia rozprawy ${ }^{22}$. Z drugiej strony ustawa nie może zobowiązywać do dokonywania czynności niemożliwych do przeprowadzenia i niezdatnych do wywołania zamierzonego skutku.

Analizując zagadnienie od strony wykładni art. $402 \S 1$ k.p.k., trzeba zaś zastanowić się, czy logiczną konsekwencją stwierdzenia, że ,jeżeli przewodniczący, zarządzając przerwę, oznaczy jednocześnie czas i miejsce dalszego ciągu rozprawy, osoby obecne na rozprawie przerwanej są obowiązane stawić się w nowym terminie bez wezwania", rzeczywiście musi być dopuszczalność wnioskowania a contrario w odniesieniu do osób nieobecnych. Wydaje się, że pomimo wrażenia, iż regulacja ta ma charakter zamknięty i wyczerpujący ${ }^{23}$, to jednak wnioskowaniu a contrario sprzeciwiać się w tym wypadku powinien wzgląd na skutki takiej wykładni. Jak wyżej wskazano, jej rezultat prowadzi do

19 Por. J. Kudrelek, Zasada ciagtości..., s. 130-131 oraz wskazane tam poglądy doktryny i orzecznictwa. Należy podnieść, że w teorii prawa przyjęto, iż odstąpienie od ścisłej wykładni językowej na rzecz wykładni funkcjonalnej jest wręcz nieodzowne, m.in. gdy ustalenie znaczenia przepisu ze względu na jego kontekst językowy prowadzi do skutków niezamierzonych oraz niezgodnych z celami instytucji, którą określa interpretowany przepis; por. J. Wróblewski, Sadowe stosowanie prawa, Warszawa 1988, s. 143-144.

${ }^{20}$ Praktyczną niemożliwość zawiadamiania stron w takich sytuacjach zauważają też: J. Tylman, w: T. Grzegorczyk, J. Tylman, op. cit., s. 810-811; J. Tylman, w: M. Siewierski, J. Tylman, M. Olszewski, Postepowanie karne w zarysie, Warszawa 1974, s. 239; L. K. Paprzycki, w: J. Grajewski, L. K. Paprzycki, S. Steinborn, op. cit., s. 1226. Por. $\$ 68$ ust. 3 rozporządzenia Ministra Sprawiedliwości z 23 lutego 2007 r. -Regulamin urzędowania sądów powszechnych (Dz. U. Nr 38, poz. 249 ze zm.), który przewiduje również dokonywanie doręczeń m.in. przez sądową służbę doręczeniową, pracownika sądowego czy policję sądową, jeżeli przyczyni się to do większej skuteczności doręczeń.

${ }^{21}$ Por. także wymogi przewidziane w $\$ 73$ ust. 1 Regulaminu urzędowania sądów powszechnych.

${ }^{22}$ Por. T. Nowak, w: T. Nowak, S. Stachowiak, Prawo karne procesowe. Dynamika postepowania, Bydgoszcz 2000, s. 121; J. Kudrelek, Zasada ciagtości..., s. 130, 246.

${ }^{23}$ L. Morawski, Zasady wyktadni prawa, Toruń 2010, s. 246. 
rozstrzygnięcia, które wydaje się rażąco nieracjonalne i podważające ratio legis interpretowanego przepisu, co $\mathrm{w}$ teorii prawa uważane jest za przesłankę niedopuszczalności tego rodzaju wnioskowania ${ }^{24}$. Instytucja przerwy w rozprawie została przewidziana jako forma naruszenia ciagłości rozprawy z przyczyn o charakterze krótkotrwałym, która w zasadzie pociąga za sobą prowadzenie rozprawy $\mathrm{w}$ nowym terminie $\mathrm{w}$ dalszym ciagu, czyli powinna $\mathrm{w}$ jak najmniejszym stopniu wpływać na jej przebieg. Przerwa w rozprawie, w szczególności zarządzona na krótki okres (gdy rozprawa jest kontynuowana tego samego dnia), nie ma $\mathrm{w}$ gruncie rzeczy wpływu na bieg postępowania jurysdykcyjnego i jest $\mathrm{w}$ praktyce traktowana jako ten sam termin rozprawy. Skoro strona nie stawiła się na dany termin rozprawy, będąc o nim prawidłowo powiadomiona, to uzasadnione jest oczekiwanie od niej realizacji ciężaru procesowego w postaci powzięcia wiadomości o przebiegu rozprawy podczas jej nieobecności, $\mathrm{w}$ tym o zarządzeniu przerwy ${ }^{25}$. Wychodząc $\mathrm{z}$ tego założenia, można twierdzić, że ratio legis art. 402 § 1 k.p.k. podkreśla ciaggłość procedowania na rozprawie po jej przerwaniu i kontynuowanie postępowania $\mathrm{w}$ analogicznym układzie procesowym. Przepis ten nie stanowi zatem regulacji zamkniętej i wyczerpującej, a poza swym zakresem pozostawia materię odnoszącą się do nieobecnych uczestników, co wydaje się sprzeciwiać stosowaniu wnioskowań a contrario.

Po rozważeniu zaprezentowanych przeciwstawnych racji wypadałoby zaproponować przyjęcie kompromisowego rozwiązania. Mianowicie z zakresu przewidzianego $\mathrm{w}$ powyżej wymienionych przepisach Kodeksu zobowiązania sądu do zawiadamiania nieobecnego na rozprawie oskarżonego o czasie i miejscu jej kontynuowania po przerwie należałoby wyłączyć sytuacje, w których zawiadomienie to oraz potencjalne stawiennictwo przez oskarżonego po przerwie jest - ze względu na bardzo krótki czas jej trwania - w sposób oczywisty niemożliwe (np. w celu oczekiwania na stawiennictwo świadków wezwanych na późniejszą porę dnia ${ }^{26}$. Przepisów nakazujących zawiadamianie nieobecnego oskarżonego o kolejnym terminie rozprawy przerwanej nie powinno się bowiem interpretować jako zakazu przerywania rozprawy na bardzo krótkie okresy. Tak więc wydaje się, że długość zarządzonej przerwy,

${ }^{24}$ Ibidem, s. 87 i 247.

${ }^{25}$ Wskazać w tym miejscu trzeba, że Sąd Najwyższy słusznie podkreślił znaczenie realizacji ciężarów procesowych dla sytuacji prawnej oskarżonego, uznając, iż brak elementarnej dbałości o własne sprawy, przejawiający się w zaniechaniu zasięgnięcia informacji o sposobie rozstrzygnięcia wniosku oskarżonego o odroczenie rozprawy, wyklucza uznanie, że spowodowane tym zaniechaniem uchybienie terminowi nastąpiło z przyczyny od strony niezależnej (postanowienie z 29 maja 2009 r., IV KZ 34/09, OSNKW 2009, z. 10, poz. 88). W innym judykacie Sąd Najwyższy zasadnie zauważył, że sąd nie ma obowiązku wykazywania większej troski o prawa oskarżonego, niż on sam to czyni (postanowienie z 3 marca 2009 r., III KK 330/08, Lex, nr 491166).

${ }^{26}$ Podobną myśl można - jak się wydaje - odczytać ze stwierdzenia L. K. Paprzyckiego, który zauważył, że przepis art. $402 \S 1$ k.p.k. dotyczy też przerwy kilkuminutowej i w takim wypadku przewodniczący składu orzekającego informuje o długości przerwy oraz o tym, że określone osoby nie mogą się oddalać, ponieważ sąd po przerwie podejmie czynności. Wynika z tego, że w sytuacji tak krótkiej przerwy autor ten zdaje się stać na stanowisku, iż czynności te czynią zadość obowiązkom sądu związanym z zarządzeniem przerwy. Por. bliżej L. K. Paprzycki, w: J. Grajewski, L. K. Paprzycki, S. Steinborn, op. cit., s. 1226. 
przy wyłączeniu obowiązku zawiadamiania oskarżonego, nie powinna przekraczać jednego dnia. W przeciwnym wypadku rozprawę należy przerwać na dłuższy okres, umożliwiający zarówno skuteczne zawiadomienie oskarżonego, jak i jego stawiennictwo po przerwie. Niezawiadomienie strony (w szczególności oskarżonego) - w warunkach wyżej opisanych - o czasie i miejscu kontynuowania rozprawy po przerwie nie powinno zatem być uznane za przyczynę uchylenia orzeczenia z art. $439 \S 1$ pkt 11 czy też art. 438 pkt 2 k.p.k. ${ }^{27}$

Jest przy tym oczywiste, że jeżeli sąd uzna za konieczne stawiennictwo danego nieobecnego na rozprawie uczestnika po przerwie, winien go na ten termin osobno wezwać i wyznaczyć jego datę stosownie do możliwości skutecznego wezwania oraz spowodowania stawiennictwa ${ }^{28}$. W szczególności musi to nastapić z przyczyn procesowych $\mathrm{w}$ sytuacji, gdy sąd po przerwie zamierza prowadzić rozprawę od początku.

Skoro brak wyraźnych unormowań nakazujących zawiadamianie nieobecnych stron o czasie i miejscu odroczenia wydania wyroku (art. $411 \S 1$ k.p.k.), uznać trzeba, że obowiązek taki nie występuje ${ }^{29}$. Porównując tę instytucję z przerwą w rozprawie, należy odnotować jeszcze silniejsze racje przemawiające za brakiem takiej konieczności, gdyż w omawianej sytuacji obowiązuje bardzo krótki, siedmiodniowy termin wraz z restrykcyjnymi skutkami prawnymi jego niedochowania (art. $411 \S 2$ k.p.k.). Okres ten w większości wypadków nie zapewnia możliwości dokonania skutecznych zawiadomień, i to na tyle wcześnie, by zainteresowany był w stanie stawić się na ogłoszenie wyroku. Dodatkowo trzeba zauważyć, że choć ogłoszenie wyroku jest częścią rozprawy głównej, zgodnie z art. 419 § 1 k.p.k. obecność stron, obrońców i pełnomocników na ogłoszeniu nie jest obowiązkowa.

Tak krótki termin wskazany w art. $411 \S 1$ k.p.k. ma uzasadnienie w tym, by sąd przystąpił do narady nad wyrokiem w tej sytuacji, gdy pozostaje bezpośrednio pod wrażeniem wystąpienia stron i aby wskutek upływu czasu zasób informacji o sprawie nie uległ zubożeniu albo znacznemu pomniejszeniu, co niewątpliwie mieć może wpływ na treść wyroku ${ }^{30}$. W konsekwencji im krótszy termin odroczenia wydania wyroku, tym jest to korzystniejsze $\mathrm{z}$ punktu widzenia zasad ciaggłości rozprawy i bezpośredniości. W skrajnych wypadkach (odroczenie na jeden, dwa dni) często nie będzie w praktyce w ogóle możliwe zawiadomienie nieobecnego na rozprawie oskarżonego o terminie wydania wyroku $^{31}$. Dlatego podzielić należy pogląd, że nieobecność strony, w tym

${ }^{27}$ Warto zaznaczyć, że w doktrynie obowiązek zawiadamiania oskarżonego, który oświadczył, iż nie jest zainteresowany i nie chce brać udziału w rozprawie, o kolejnym terminie rozprawy słusznie uznano za przejaw nieuzasadnionej, nadmiernej troski ustawodawcy o oskarżonego, wręcz „naprzykrzania” się przez sąd oskarżonemu; por. M. Urbaniak, Prowadzenie rozprawy pod nieobecność oskarżonego - art. 377 k.p.k., „Prokuratura i Prawo” 2002, nr 3, s. 55-56. Tak samo J. Kudrelek, Obecność oskarżonego..., s. 67, który zasadnie zauważa, że nie znajduje uzasadnienia nakłanianie przez sąd oskarżonego do zmiany oświadczenia o niebraniu udziału, a w tej sytuacji oczekiwanie sądu na poświadczenie, iż pismo zostało doręczone oskarżonemu, będzie tylko nieuzasadnionym przewlekaniem procesu.

28 A. Bojańczyk, T. Razowski, op. cit., s. 65.

${ }^{29}$ Por. postanowienie Sądu Najwyższego z 14 kwietnia 2005 r., II KZ 14/05, Lex, nr 149627.

${ }^{30}$ Por. wyrok Sądu Najwyższego z 28 lutego 1983 r., II KR 25/83, OSNKW 1983, z. 9, poz. 78.

31 Tak Sąd Najwyższy w uzasadnieniu wyroku z 6 listopada 2003 r., IV KK 456/02, OSNKW 2004, z. 3, poz. 23 . 
oskarżonego, na rozprawie, na której podjęto postanowienie o odroczeniu wydania wyroku, nie rodzi po stronie sądu obowiązku podjęcia czynności zmierzającej do zawiadomienia jej o terminie publikacyjnym ${ }^{32}$. Odmienny pogląd, zakładający obowiązek zawiadamiania oraz - w razie niemożności jego dokonania - ocenę in casu wpływu niezawiadomienia na treść wyroku jako względnej przyczyny odwoławczej ${ }^{33}$, nie może zasługiwać na akceptację ze względu na zbytnią uznaniowość i niewynikające $\mathrm{z}$ ustawy zawężanie możliwości stosowania art. 411 k.p.k. Jest jednak oczywiste, że w sytuacji usprawiedliwionego niestawiennictwa strony na ogłoszeniu wyroku w celu jego zaskarżenia, w razie zaistnienia przesłanek ustawowych, można i należy skorzystać z instytucji przywrócenia odpowiedniego terminu zawitego (art. 126 $\S 1$ k.p.k.).

Wznowienie przewodu sądowego (art. 409 k.p.k.) stanowi w swej istocie cofnięcie postępowania z fazy wyrokowania do fazy sprzed ogłoszenia zarządzenia o zamknięciu przewodu ${ }^{34}$, dlatego też podjęcie decyzji procesowej o wznowieniu i wyznaczeniu nowego terminu rozprawy wymaga $\mathrm{w}$ konsekwencji wezwania lub zawiadomienia o nim wszystkich stron. Decyzja ta zapowiada bowiem, że mimo uprzedniego zakończenia postępowania dowodowego będzie $\mathrm{w}$ dalszym ciągu następowało merytoryczne rozpoznawanie sprawy.

$\mathrm{Z}$ kolei instytucja odroczenia rozprawy (art. 404 k.p.k.), mimo pewnych podobieństw do przerwy, ma odmienną od niej naturę prawna, co pociaga za sobą konsekwencje również na gruncie omawianych zagadnień. Przede wszystkim zaakcentować trzeba, że odroczenie rozprawy stanowi dalej idące odstępstwo od zasady koncentracji procesu ${ }^{35}$. Ustawa bowiem formułuje regułę, że rozprawa odroczona prowadzona jest w nowym terminie od początku i dla podjęcia decyzji w tym przedmiocie nie wystarcza zarządzenie przewodniczącego, a konieczne jest postanowienie sądu. Odroczenie rozprawy może nastąpić, jeżeli od początku wiadomo, że nie będzie ona mogła być kontynuowana przed upływem $35 \mathrm{dni}$. Brak pewności co do tej kwestii powinien implikować zarządzenie przerwy $\mathrm{w}$ rozprawie ${ }^{36}$. Powyższe cechy odroczenia rozprawy świadczą o tym, że jest to instytucja wyjątkowa, którą należy stosować $\mathrm{z}$ dużą rozwagą i umiarem. Ponadto nieokreślenie $\mathrm{w}$ ustawie maksymalnego okresu trwania odroczenia może w niektórych wypadkach długotrwałego stosowania tej instytucji $\mathrm{w}$ istocie prowadzić do przekreślenia zasady koncentracji procesu ${ }^{37}$.

Te uwarunkowania prawne instytucji odroczenia rozprawy skłaniaja - inaczej niż w wypadku przerwy - do przyjęcia poglądu, wedle którego w razie odroczenia rozprawy, niezależnie od tego, czy jednocześnie oznaczono miejsce

${ }^{32}$ Postanowienie Sądu Najwyższego z 14 kwietnia 2005 r., II KZ 14/05, Lex, nr 149627.

${ }^{33}$ Wyrok Sądu Najwyższego z 6 listopada 2003 r., IV KK 456/02, OSNKW 2004, z. 3, poz. 23.

${ }^{34}$ Por. przykładowo J. Grajewski, Przebieg procesu karnego, Warszawa 2012, s. 255.

${ }^{35}$ Por. bliżej J. Kudrelek, Zasada ciagtości..., s. 247 i n.

${ }^{36}$ R. A. Stefański, w: Kodeks postepowania..., t. 2, s. 774.

${ }^{37}$ Por. wyroki Sądu Najwyższego: z 28 lipca 1995 r., II KRN 55/95, „Prokuratura i Prawo” - wkładka „Orzecznictwo” 1996, nr 2-3, poz. 11; z 7 października 1998 r., V KKN 271/97, OSNKW 1998, z. 11-12, poz. 55; T. Grzegorczyk, Kodeks postepowania karnego. Komentarz, Warszawa 2008, s. 857. 
i termin jej kontynuacji, zachodzi konieczność wezwania na nowy termin uczestników, którzy maja obowiązek stawiennictwa, a nie byli obecni na rozprawie odroczonej, oraz zawiadomienia tych, którzy nie byli obecni na rozprawie odroczonej, a maja prawo stawić się na rozprawę w nowym terminie. Należy także zwrócić uwagę na to, że zasadniczo rozprawę odroczoną prowadzi się w nowym terminie od początku (art. $404 \S 2$ zd. pierwsze k.p.k.), co samo w sobie ma ważkie następstwa prawne dla interesów procesowych poszczególnych stron, uzasadnia bowiem bezwzględną konieczność zawiadamiania ich o kolejnym terminie.

W związku z tym rozważenia wymaga jeszcze zagadnienie, czy istnieje obowiązek odrębnego wzywania, z zastosowaniem przepisów rozdziału 15 k.p.k., uczestników obecnych na rozprawie odroczonej, wówczas gdy jednocześnie $\mathrm{z}$ odroczeniem rozprawy został wskazany czas i miejsce dalszego jej ciagu. Kodeks postępowania karnego milczy $\mathrm{w}$ tej kwestii $\mathrm{w}$ przeciwieństwie do regulacji art. $79 \S 2 \mathrm{w}$ zw. z $§ 3$ k.p.s.w., która wyraźnie stanowi, że w razie odroczenia rozprawy na określony termin osoby obecne na rozprawie poucza się o obowiązku stawiennictwa bez wezwania. Powstaje pytanie, jak należy $\mathrm{w}$ takiej sytuacji postapić $\mathrm{w}$ związku $\mathrm{z}$ odroczeniem rozprawy $\mathrm{w}$ sprawie karnej. Wykładnia językowa (art. $402 \S 1$ a contrario, art. $117 \S 1$ k.p.k.) prowadzi do przyjęcia obowiązku każdorazowego odrębnego zawiadamiania wszystkich obecnych stron o czasie i miejscu dalszego ciagu rozprawy w wypadku jej odroczenia wraz $\mathrm{z}$ jednoczesnym wskazaniem nowego terminu. Stanowisko takie należałoby uznać jednak za zbyt formalistyczne. Ustne zawiadomienie osób obecnych na rozprawie odroczonej o czasie i miejscu jej kontynuowania spełnia najlepiej funkcję informacyjną, gdyż trafia ono bezpośrednio do zainteresowanych $\mathrm{w}$ obecności organu, który ma odtąd pewność, że uczestnicy ci sa prawidłowo zawiadomieni (wezwani) o tym terminie. Do paradoksalnej sytuacji mogłoby zwłaszcza dojść, gdyby strona obecna na rozprawie odroczonej osobiście zawiadomiona o jej kolejnym terminie nie odebrała wysłanego do niej zawiadomienia, które byłoby przy tym niewłaściwie awizowane (por. art. $133 \S 2$ k.p.k.). Ze ściśle formalnego punktu widzenia $\mathrm{w}$ razie niestawiennictwa tej strony na kolejnym terminie należałoby uznać, że nie została ona o nim prawidłowo zawiadomiona. Wydaje się zatem, że uzasadnione jest $\mathrm{w}$ tym wypadku skorzystanie per analogiam $\mathrm{z}$ regulacji art. $79 \S 2 \mathrm{w}$ zw. z $\S 3$ k.p.s.w., pomimo że została ona wprowadzona do procedury wykroczeniowej celem jej uproszczenia i przyspieszenia w stosunku do postępowania $\mathrm{w}$ sprawach o przestępstwa. Dodatkowo można wskazać, że wykładnia taka znajduje pośrednie uzasadnienie w treści art. 142 k.p.k. ${ }^{38}$ oraz że upowszechniła się ona w praktyce sądów ${ }^{39}$.

${ }^{38}$ Chodzi o to, że art. 142 k.p.k. dotyczy sytuacji, gdy osoba zainteresowana przekazuje swe oświadczenie a posteriori, a w rozpatrywanym wypadku jest ona adresatem oświadczenia $a$ priori, czyli przed tym, gdy można dokonać doręczenia.

${ }^{39}$ Sąd Najwyższy przyjął na gruncie Kodeksu postępowania karnego z 1928 r., że oskarżony powiadomiony przez przewodniczącego ustnie na rozprawie odroczonej o terminie i miejscu następnej rozprawy obowiązany jest stawić się w nowym terminie bez osobnego wezwania; por. uchwałę z 28 kwietnia 1960 r., VI KO 6/60, OSNPG 1960, z. 7, poz. 125. 
Analizując wyniki egzegezy unormowań prawnych dotyczących zawiadamiania stron $\mathrm{w}$ powyżej wskazanych wypadkach przerwania ciagłości rozprawy, trzeba zauważyć, że do istoty gwarancji procesowych stron należą w tym aspekcie dwa elementy: umożliwienie stronie zapoznania się z informacja o czasie i miejscu dalszego ciągu rozprawy oraz umożliwienie jej wzięcia udziału w dalszym ciągu rozprawy.

Ponadto podkreślenia wymaga słuszne stanowisko, że strony mają prawo do udziału w rozprawie, jednakże nie jest powinnością sądu upewnienie się, czy strona, a w tym oskarżony, niestawiająca się na rozprawę zawiniła niestawiennictwo, ale obowiązkiem strony jest wykazać bez oddzielnych wezwań, że niestawiennictwo było niezawinione ${ }^{40}$. Nie wyklucza to oczywiście zaistnienia przewidzianych $\mathrm{w}$ ustawie sytuacji, w których sąd może in casu uznać tę obecność za niezbędną i od niej uzależnić kontynuowanie rozprawy (np. art. 377 $\S 3$, art. $384 \S 3$ k.p.k.). Jednakże wyraźne brzmienie ustawy i brak przewidzianych wyjątków w tym zakresie wskazują, że unormowania te nie dotyczą oskarżyciela publicznego w postępowaniu zwyczajnym (art. 46 k.p.k.). Reguła powyższa zdaje się odpowiadać przyjętym standardom rzetelnego procesu. Europejski Trybunał Praw Człowieka pod pewnymi warunkami dopuszcza przeprowadzenie rozprawy pod nieobecność oskarżonego, nie jest to bowiem prawo absolutne. Po pierwsze, może to mieć miejsce, jeśli sam oskarżony z tego prawa zrezygnował; po drugie, jeżeli wymaga tego dobro wymiaru sprawiedliwości, a sąd działał $\mathrm{z}$ właściwa starannością, chociaż bezskutecznie, aby powiadomić oskarżonego o rozprawie ${ }^{41}$. W rozpatrywanej kwestii chodzi o pierwsza sytuację. Prawidłowo zawiadomiona (wezwana) strona niestawiająca się na rozprawę bez usprawiedliwienia, czyli świadomie rezygnująca $\mathrm{z}$ prawa do wzięcia $\mathrm{w}$ niej udziału, nie powinna oczekiwać, że tylko $\mathrm{z}$ tego względu wykluczone będzie przerwanie rozprawy albo odroczenie wydania wyroku. W świetle wspomnianego rozumienia standardów rzetelnego procesu trzeba przyjąć, że sąd dołożył należytych starań, aby powiadomić stronę o rozprawie ${ }^{42}$.

Należy też zauważyć, że przedstawione powyżej zapatrywania nie stoja $\mathrm{w}$ kolizji z nowo wprowadzona podstawą wznowienia postępowania, wyrażona w art. 540b $\S 1$ pkt 1 k.p.k. Po pierwsze bowiem przepis ten nie przesądza, $\mathrm{w}$ jakich sytuacjach należy doręczać oskarżonemu zawiadomienie o rozprawie. Po drugie zaś - co jeszcze istotniejsze - w razie osobistego pouczenia oskarżonego przed rozpoczęciem rozprawy o regulacjach przewidujących brak

\footnotetext{
${ }^{40}$ Por. na ten temat obszernie, z przytoczeniem orzecznictwa, S. Steinborn, w: J. Grajewski, L. K. Paprzycki, S. Steinborn, op. cit., s. 414-416.

${ }^{41}$ Obszernie na ten temat pisze C. Nowak, w: P. Wiliński (red.), Rzetelny proces karny $w$ orzecznictwie sadów polskich $i$ międzynarodowych, Warszawa 2009, s. 139, przytaczając orzecznictwo ETPC; por. także H. Kuczyńska, w: ibidem, s. 163-164. Jeszcze dalej poszedł w starszym judykacie (z 1985 r.) ETPC, uznając, że nie narusza prawa do osobistego uczestnictwa w rozprawie regulacja, według której oskarżony nie musi być zawiadomiony o terminie rozprawy, a w celu wyegzekwowania przysługującego mu uprawnienia do uczestnictwa sam musi się o tym terminie dowiadywać; wyrok ten przytacza P. Hofmański, Konwencja europejska a prawo karne, Toruń 1995, s. 244.

${ }^{42} \mathrm{~W}$ odniesieniu do wymogu podjęcia przez sąd określonych środków w celu zapewnienia obecności oskarżonego na rozprawie por. H. Kuczyńska, w: P. Wiliński (red.), op. cit., s. 164, przyp. 47.
} 
obowiązku zawiadamiania go o terminie rozprawy przerwanej i terminie ogłoszenia wyroku w wypadku odroczenia jego wydania i tym samym o możliwości wydania orzeczenia pod jego nieobecność, nie będzie on mógł skorzystać z tej podstawy wznowienia. Niezależnie od tego możliwość wznowienia wyłączona jest $\mathrm{z}$ mocy samego prawa w wypadkach wskazanych $\mathrm{w}$ art. $540 \mathrm{~b} \S 2$ k.p.k.

Na zakończenie warto odnieść się do planowanej nowelizacji ustawy procesowej zawartej w projekcie ustawy o zmianie ustawy - Kodeks postępowania karnego, ustawy - Kodeks karny i niektórych innych ustaw, przygotowanym przez Komisję Kodyfikacyjna Prawa Karnego, działająca przy Ministrze Sprawiedliwości, który został w listopadzie 2012 r. wniesiony przez Radę Ministrów do Sejmu. Projekt ten istotnie modyfikuje zasady udziału oskarżonego na rozprawie, gdyż co do zasady wprowadza jedynie prawo, a nie obowiązek tego udziału (z wyjątkami odnoszącymi się do oskarżonego o zbrodnię w zakresie niektórych czynności oraz gdy przewodniczący lub sąd inaczej zadecyduje - por. art. $374 \S 1$ i 1a k.p.k. według projektu). Nie zmienia zaś ogólnej reguły art. 117 § 1 k.p.k., nakazującej zawiadamiane uprawnionego o czasie i miejscu czynności procesowej, choć projektowany przepis art. 349 $\S 8$ k.p.k., regulujący wyznaczanie tzw. posiedzenia wstępnego, przyjmuje, że ogłoszenie zarządzenia o wyznaczeniu terminów rozprawy ma skutek równoznaczny z wezwaniem obecnych uczestników postępowania do udziału w rozprawie albo zawiadomieniem o jej terminie. Projekt rezygnuje też $\mathrm{z}$ paternalistycznej postawy wobec oskarżonego, który z zawinionych przyczyn wprawił się w stan niezdolności do udziału w postępowaniu czy nie stawił się na termin rozprawy (uchylenie art. $377 \S 5$ k.p.k.) i zwalnia sąd z obowiązku powiadamiania oskarżonego o terminach rozprawy przerwanej albo odroczonej. Daleko idąca zmianą jest też proponowane brzmienie art. $402 \S 1$ k.p.k., który w sytuacji gdy przewodniczący, zarządzając przerwę, oznaczy jednocześnie czas i miejsce dalszego ciagu rozprawy, nie wymaga zawiadamiania o nowym terminie osób jedynie uprawnionych do stawiennictwa, nawet gdy nie uczestniczyły w rozprawie przerwanej.

Zmiany te należy uznać za idące we właściwym kierunku i porządkujące omawiane zagadnienie na gruncie zarządzania przerwy w rozprawie, lecz tylko $\mathrm{w}$ odniesieniu do stron uprawnionych do uczestnictwa w tej czynności procesowej. Natomiast nadal otwarte pozostają omówione wyżej sporne kwestie na tle zawiadamiania stron $\mathrm{w}$ wypadkach, w których maja obowiązek udziału $\mathrm{w}$ rozprawie, oraz $\mathrm{w}$ zwiazku $\mathrm{z}$ odroczeniem rozprawy i odroczeniem wydania wyroku. Wymagają one również zainteresowania ustawodawcy.

dr Piotr Rogoziński

Uniwersytet Gdański

piotr.rogozinski@wp.pl 


\section{OBLIGATION TO NOTIFY PARTIES OF THE CONTINUATION OF A HEARING IN THE ASPECT OF PROCEEDINGS SECURITIES AND THE PRINCIPLE OF PROCESS CONCENTRATION}

\section{Summary}

The paper refers to the issue of a court's obligation to notify the parties to a hearing of its continuation. Implementation of a mechanism ensuring that parties to a trial are given a real opportunity to engage in a hearing proves that a given legal system respects the most important rules and proceedings securities. The obligation to notify the parties of the continuation of a hearing should be considered in relation to the proceedings securities of the parties and the principle of the concentration of the process, because these concepts reflect the directions of the major interests that clash in a trial, namely the individual interests (mainly of the parties) and the public interest. Those interests are frequently divergent.

The issue of notifying the parties of the continuation of a hearing occurs when there is a break in the process. Pursuant to the existing laws, this happens in connection with the following: suspension of the proceedings, postponement of the hearing, break in the hearing, adjournment of the passing of the judgment and reopening of the hearing. Doubts arise especially in the event when a hearing is being adjourned and a new time and place where it will be continued is announced but not all the parties are present at the time of the announcement of a decision to discontinue the hearing. The paper attempts to analyse some important issues that arise in relation to the above. 
Copyright of Journal of Law, Economics and Sociology is the property of Faculty of Law and Administration of Adam Mickiewicz University in Poznan and its content may not be copied or emailed to multiple sites or posted to a listserv without the copyright holder's express written permission. However, users may print, download, or email articles for individual use.

Właścicielem praw autorskich do „Ruchu Prawniczego, Ekonomicznego i Socjologicznego” jest Wydział Prawa i Administracji Uniwersytetu im. Adama Mickiewicza w Poznaniu. Zawartość czasopisma nie może być kopiowana, przesyłana do innych stron internetowych bądź zamieszczana na blogach bez pisemnej zgody wydawcy. Niemniej artykuły można drukować, kopiować lub przesyłać w formie elektronicznej na własny użytek. 